\title{
Perventricular repair of ventricular septal defects: Specific techniques have specific risks
}

\author{
Ryan R. Davies, MD, FACS
}

\author{
From the Nemours Cardiac Center, A.I. duPont Hospital for Children, Wilmington, Del; and the Thomas Jefferson \\ University, Philadelphia, Pa. \\ Disclosures: Author has nothing to disclose with regard to commercial support. \\ Received for publication Jan 18, 2016; accepted for publication Jan 18, 2016; available ahead of print Feb 6, 2016. \\ Address for reprints: Ryan R. Davies, MD, FACS, Nemours Cardiac Center, A.I. duPont Hospital for Children, \\ 1600 Rockland Rd, Wilmington, DE 19803 (E-mail: rdavies@ nemours.org). \\ J Thorac Cardiovasc Surg 2016;151:e87-8 \\ $0022-5223 / \$ 36.00$ \\ Copyright (C) 2016 by The American Association for Thoracic Surgery \\ http://dx.doi.org/10.1016/j.jtcvs.2016.01.024
}

Hemodynamically significant muscular ventricular septal defects (VSDs) - particularly those of the apical or anterior muscular septum-present an important management challenge. Historically the results of conventional surgical repair have been suboptimal, with significant early and late morbidity. ${ }^{1}$ Other options include surgical palliation and percutaneous device occlusion, but recently hybrid approaches to these defects have grown in popularity.

Techniques for hybrid closure have evolved with time. Perventricular closure was first reported without the use of cardiopulmonary bypass (CPB) by Amin and colleagues ${ }^{2}$ in 1998. "Hybrid" closure of muscular VSDs may involve a variety of techniques, however, on or off $\mathrm{CPB}$, with or without cardioplegic myocardial arrest, during concomitant surgical procedures or not, and through a perventricular, peratrial, or transatriotomy approach. Each of these techniques carries specific risks.

Kumar and Knott-Craig's report ${ }^{3}$ in this issue of the Journal is a novel description of a complication of a perventricular approach to closure of an apical muscular VSD. The hybrid procedure in this case was performed with CPB. After a protracted postoperative course, it was discovered that the left-sided disk of the occluder had entrapped the lateral wall of the left ventricle near one of the papillary muscles, resulting in poor ventricular filling and mitral regurgitation. The device was subsequently removed, and the VSD was closed through a left ventriculotomy.

This case has several important lessons. In general, it serves as a reminder that hybrid procedures are neither inherently without risk nor necessarily better than the traditional surgical (or percutaneous) approaches. As Kumar and $\mathrm{Knott}_{-\mathrm{Craig}^{3}}$ note, other complications of device occlusion of VSDs have been described, including ventricular perforation, heart block, device embolization, and death. Kumar and Knott-Craig ${ }^{3}$ suggest that given these risks surgical repair through a left ventriculotomy might be preferable for closure of apical muscular VSDs. Surgical closure through a ventriculotomy, however, is also not without

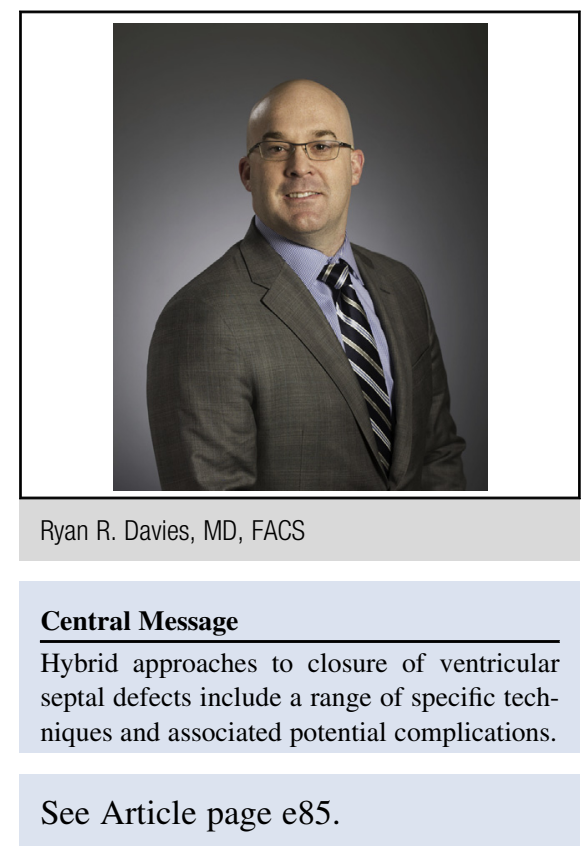

risks. ${ }^{1,4}$ The decision to proceed with a hybrid approach should be based on a collaborative approach between interventionalists and surgeons with an understanding of the risks and benefits in a specific case.

More specifically, in this case the placement of the device during CPB may have contributed to the risk of this complication. In the setting of a primum atrial septal defect, CPB has the potential to completely decompress both sides of the heart. In our experience, we often deploy the occluder before CPB. Especially in the small heart, this maintains left ventricular size and mitigates the risk of entrapping left ventricular structures including papillary muscles. When using a perventricular approach during CPB, leaving volume in the heart may lower the risk of a similar complication. Finally, this report suggests that detailed examination of the relationship between the device and the left ventricular free wall and papillary muscles is a critical component of the intraoperative echocardiographic examination.

With the increasing use of hybrid procedures, reports such as this are critical to appropriate procedural selection and periprocedural management. Kumar and Knott-Craig ${ }^{3}$ are to be congratulated both for their recognition and management of the complication and for the clarity of their report. 


\section{References}

1. Griffiths SP, Turi GK, Ellis K, Krongrad E, Swift LH, Gersony WM, et al. Muscular ventricular septal defects repaired with left ventriculotomy. Am J Cardiol. 1981;48:877-86.

2. Amin Z, Berry JM, Foker JE, Rocchini AP, Bass JL. Intraoperative closure of muscular ventricular septal defect in a canine model and application of the technique in a baby. J Thorac Cardiovasc Surg. 1998;115:1374-6.
3. Kumar TK, Knott-Craig CJ. Rare life-threatening complication of device closure of ventricular septal defect in a child. J Thorac Cardiovasc Surg. 2016; 151:e85-6.

4. Myhre U, Duncan BW, Mee RB, Joshi R, Seshadri SG, Herrera-Verdugo O, et al. Apical right ventriculotomy for closure of apical ventricular septal defects. Ann Thorac Surg. 2004;78:204-8. 